\title{
Procalcitonin as a marker of bacterial sepsis in immunocompromised patients
}

\author{
Lana Gatserelia*, Lali Sharvadze, Marine Karchava, Nino Babridze, Tengiz Tsetvadze, Natia Dvali, Lela Dzigua, \\ Nika Chxartishvili
}

From 17th International Symposium on HIV and Emerging Infectious Diseases (ISHEID) Marseille, France. 23-25 May 2012

\section{Introduction}

Procalcitonin (PCT) is a recently described marker of severe sepsis. It was decided to assess the value of PCT as a marker of secondary infection in patients infected with HIV in Georgian AIDS Center.

\section{Materials and methods}

PCT plasma levels were measured by quantitative assay BRAHMS-Biomérieux using the VIDAS analyser in a prospective study in 135 HIV-infected individuals: 87 asymptomatic and 48 with lever or suspected secondary infections.

\section{Results}

The baseline plasma level of PCT was $(0.5 \mathrm{ng} / \mathrm{ml}+/-0.5)$, even in the latest stages of the disease, and did not differ from the values of healthy subjects $(0.54 \mathrm{ng} / \mathrm{ml}+/-0.1)$. EDTA-treated whole blood was collected from patients before starting specific antimicrobial therapy. No elevation of PCT level was detected in HIV-infected patients with evolving secondary infections including PCP $(\mathrm{n}=4)$, cerebral toxoplasmosis $(n=5)$, viral infections $(n=9)$, mycobacterial infections $(\mathrm{n}=4)$, localized bacterial $(\mathrm{n}=$ 13) and fungal infections $(\mathrm{n}=4)$, and in various associated infectious and non-infectious febrile events $(\mathrm{n}=$ 15). All these plasma values were lower than $2 \mathrm{ng} / \mathrm{ml}$. In contrast, high PCT plasma levels were detected in one HIV-infected patient with a septicaemic influenza infection $(17 \mathrm{ng} / \mathrm{ml})$ and another one with a septicaemic Pneudomonas aeruginosa infection ( $46 \mathrm{ng} / \mathrm{ml}), \mathrm{PCT}$ values decreased rapidly under appropriate therapy.

* Correspondence: Igatserelia@yahoo.com

Head of Virology Lab. at Infectious Diseases, Aids and Clinical Immunology Research Center, Tbilisi, Georgia

\section{Conclusions}

We found that PCT is a specific marker of bacterial sepsis in HIV-infected patients, as no increase in other secondary infections could be detected in those patients. A rapid determination of PCT level could be useful to verify or refute bacterial sepsis for a better management of febrile HIV-infected patients.

Published: 25 May 2012

doi:10.1186/1742-4690-9-S1-P90

Cite this article as: Gatserelia et al.: Procalcitonin as a marker of bacterial sepsis in immunocompromised patients. Retrovirology 20129 (Suppl 1):P90.

Submit your next manuscript to BioMed Central and take full advantage of:

- Convenient online submission

- Thorough peer review

- No space constraints or color figure charges

- Immediate publication on acceptance

- Inclusion in PubMed, CAS, Scopus and Google Scholar

- Research which is freely available for redistribution

Submit your manuscript at www.biomedcentral.com/submit
() Biomed Central 